\title{
Current Practice in Diagnosis and Treatment of Growth Hormone Deficiency in Childhood: A Survey from Turkey
}

Şükran Poyrazoğlu1, Teoman Akçay2, Ilknur Arslanoğlu3, Mehmet Emre Atabek4, Zeynep Atay5, Merih Berberoğlu6, Abdullah Bereket5, Aysun Bideci7, Iffet Bircan8, Ece Böber9, Şule Can10, Yaşar Cesur11, Şükran Darcan12, Korcan Demir13, Bumin Dündar10, Betül Ersoy14, Ihsan Esen15, Ayla Güven16, Cengiz Kara17, Mehmet Keskin18, Selim Kurtoğlu19, Nihal Memioğlu20, Mehmet Nuri Özbek21, Tolga Özgen11, Erkan Sarı22, Zeynep Şıklar6, Enver Şimşek23, Serap Turan5, Ediz Yeşilkaya22, Bilgin Yüksel24, Feyza Darendeliler ${ }^{1}$

\footnotetext{
1/stanbul University, Istanbul Faculty of Medicine, Department of Pediatric Endocrinology, Istanbul, Turkey

2Bakırköy Dr. Sadi Konuk Research and Training Hospital, Clinic of Pediatric Endocrinology, Istanbul, Turkey

${ }^{3}$ Düzce University Faculty of Medicine, Department of Pediatric Endocrinology, Düzce, Turkey

${ }^{4}$ Necmettin Erbakan University Faculty of Medicine, Department of Pediatric Endocrinology, Konya, Turkey

5 Marmara University Faculty of Medicine, Department of Pediatric Endocrinology, Istanbul, Turkey

6 Ankara University Faculty of Medicine, Department of Pediatric Endocrinology, Ankara, Turkey

7 Gazi University Faculty of Medicine, Department of Pediatric Endocrinology, Ankara, Turkey

8Akdeniz University Faculty of Medicine, Department of Pediatric Endocrinology, Antalya, Turkey

${ }^{9}$ Dokuz Eylül University Faculty of Medicine, Department of Pediatric Endocrinology, Izmir, Turkey

10Tepecik Educational and Research Hospital, Clinic of Pediatric Endocrinology, Izmir, Turkey

${ }^{11}$ Bezmialem Vakıf University Faculty of Medicine, Department of Pediatric Endocrinology, Istanbul, Turkey

${ }^{12}$ Ege University Faculty of Medicine, Department of Pediatric Endocrinology, Izmir, Turkey

${ }^{13}$ Dr. Behçet Uz Children Disease and Surgery Training and Research Hospital, Clinic of Pediatric Endocrinology, Izmir, Turkey

${ }^{14}$ Celal Bayar University Faculty of Medicine, Department of Pediatric Endocrinology, Manisa, Turkey

15 FIrat University Faculty of Medicine, Department of Pediatric Endocrinology, Elazığ, Turkey

16 Göztepe Educational and Research Hospital, Clinic of Pediatric Endocrinology, Istanbul, Turkey

17Ondokuz Mayıs University Faculty of Medicine, Department of Pediatric Endocrinology, Samsun, Turkey

${ }_{18}$ Gaziantep University Faculty of Medicine, Department of Pediatric Endocrinology, Gaziantep, Turkey

${ }^{19}$ Erciyes University Faculty of Medicine, Department of Pediatric Endocrinology, Kayseri, Turkey

20American Hospital, Clinic of Pediatric Endocrinology, Istanbul, Turkey

${ }^{21}$ Diyarbakır Children's State Hospital and Diyarbakır Training and Research Hospital, Diyarbakır, Turkey

22 Gülhane Military Medical Academy, Department of Pediatric Endocrinology, Ankara, Turkey

${ }^{23}$ Osman Gazi University Faculty of Medicine, Department of Pediatric Endocrinology, Eskişehir, Turkey

${ }^{24}$ Çukurova University Faculty of Medicine, Department of Pediatric Endocrinology, Adana, Turkey
}

\section{Address for Correspondence}

Şükran Poyrazoğlu MD, Istanbul University Faculty of Medicine, Department of Pediatric Endocrinology, Istanbul, Turkey

Phone: +90 414 20 00/31645 E-mail: sukranpoyrazoglu@yahoo.com

(OJournal of Clinical Research in Pediatric Endocrinology, Published by Galenos Publishing 


\section{ABSTRACT}

Objective: Approaches to diagnosis and treatment of growth hormone deficiency (GHD) in children vary among countries and even among centers in the same country. This survey, aiming to facilitate the process of preparing the new consensus on GHD by the Turkish Pediatric Endocrinology and Diabetes Society, was designed to evaluate the current practices in diagnosis and treatment of GHD in different centers in Turkey.

Methods: A questionnaire covering relevant items for diagnosis and treatment of GHD was sent out to all pediatric endocrinology centers.

Results: Twenty-four centers returned the questionnaire. The most frequently used GH stimulation test was L-dopa, followed by clonidine. Eighteen centers used a GH cut-off value of $10 \mathrm{ng} / \mathrm{mL}$ for the diagnosis of GHD; this value was $7 \mathrm{ng} / \mathrm{mL}$ in 4 centers and $5 \mathrm{ng} / \mathrm{mL}$ in 2 centers. The most frequently used assay was immunochemiluminescence for determination of $\mathrm{GH}$, insulin-like growth factor- 1 and insulin-like growth factor binding protein-3 concentrations. Sex steroid priming in both sexes was used by 19 centers. The most frequently used starting dose of recombinant human $\mathrm{GH}(\mathrm{rhGH})$ in prepubertal children was $0.025-0.030 \mathrm{mg} / \mathrm{kg} /$ day and $0.030-0.035 \mathrm{mg} / \mathrm{kg} /$ day in pubertal children. Growth velocity was used in the evaluation for growth response to rhGH therapy in all centers. Anthropometric measurements of patients every 3-6 months, fasting blood glucose, bone age and thyroid panel evaluation were used by all centers at follow-up. Main indications for cessation of therapy were decreased height velocity and advanced bone age. Fourteen centers used combined treatment (rhGH and gonadotropin-releasing analogues) to increase final height.

Conclusion: Although conformity was found among centers in Turkey in current practice, it is very important to update guideline statements and to modify, if needed, the approach to GHD over time in accordance with new evidence-based clinical studies.

Key words: Survey, growth hormone deficiency, childhood

Conflict of interest: None declared

Received: 15.12 .2014

Accepted: 05.01.2015

\section{Introduction}

The diagnosis and treatment of growth hormone deficiency (GHD) are important and challenging issues. Several prevailing guidelines for the diagnosis and treatment of GHD in children have been published $(1,2,3,4,5)$. However, differences in diagnostic procedures and treatment strategies between countries and even among centers in the same country continue to exist $(6,7)$. Recently, the Turkish Pediatric Endocrinology and Diabetes Society has been preparing new consensus guidelines for diagnostic procedures and treatment in children with GHD. We believe that this survey, based on feedback obtained from the clinicians and the results of which are presented below, is timely and will be helpful in preparing the new consensus and incorporating the recent practices into the consensus statement.

We aimed to evaluate how diagnosis and treatment of childhood GHD is currently carried out in day-to-day routine among Turkish pediatric endocrinologists.

\section{Methods}

A questionnaire was sent out via internet to all pediatric endocrinology centers $(n=44)$. Each center has at least one pediatric endocrinologist who has completed the fellowship and certificate programs. There were two general sections in the questionnaire, the first part relating to diagnosis and the second to treatment of GHD in childhood. The contents of the questionnaire are shown in Table 1. Each question could be answered by choosing several predefined options or if not suitable by a comment. Data were reported as percentage of respondents.

\section{Results}

Twenty-four centers (55\%), (19 medical schools, 4 public hospitals and 1 private hospital) responded to the questionnaire. Thus, our survey appears to be representative of current practice within Turkey. The estimated total number of patients put on recombinant human $\mathrm{GH}(\mathrm{rhGH})$ treatment per year by the respondents was 903 [mean $43 \pm 20$ (range $=4-80$ )]. Distribution of centers by number of patients followed was: 80-60 patients/year, 20.8\% (5 centers); 59-40 patients/year, 29.2\% (7 centers); 39-20 patients/year, 33.3\% (8 centers) and <20 patients/year, $16.7 \%$ (4 centers).

\section{Diagnosis of Growth Hormone Deficiency}

The diagnosis of GHD was always confirmed by two $\mathrm{GH}$ stimulation tests by all of the respondents. Choice of $\mathrm{GH}$ stimulation tests varied according to centers (Table 2). 
L-dopa test was the most frequently used $\mathrm{GH}$ stimulation test. Clonidine test was used as the second frequent test. Insulin tolerance test (ITT) and glucagon test were other tests used for stimulation.

Eighteen centers $(75 \%)$ used a cut-off value of $\mathrm{GH}$ peak of $10 \mathrm{ng} / \mathrm{mL}$ for the assessment of GHD; this value was 7 $\mathrm{ng} / \mathrm{mL}$ in 4 centers $(16.7 \%)$ and $5 \mathrm{ng} / \mathrm{mL}$ in two centers (8.3\%).

\section{Period}

Diagnosis of Growth Hormone Deficiency in the Newborn

Results of random spontaneous $\mathrm{GH}$ levels in the newborn period was reported by 18 respondents $(75 \%)$. Normality was defined as a $\mathrm{GH}$ concentration of 20 $\mathrm{ng} / \mathrm{mL}$ by 10 respondents (55.6\%), whereas 3 respondents $(16.7 \%)$ used reference values similar to those of their GH stimulation testing, as $10 \mathrm{ng} / \mathrm{mL}$. Another 5 respondents (27.8\%) reported this value as $7 \mathrm{ng} / \mathrm{mL}$.

\section{Assay for Growth Hormone}

The most frequently used $\mathrm{GH}$ assays were immunochemiluminescent assay (ICMA) $(n=21,87.5 \%)$, immunoradiometric assay (IRMA) ( $\mathrm{n}=1,4.2 \%)$ and radiommunoassay $(R I A)(n=2,8.3 \%)$. When asked which brands of assay were used for $\mathrm{GH}$ analysis, all respondents were aware of the brands of the assay they were using.

\section{Insulin-Like Growth Factor-1 (IGF-1) Assay}

When we asked what type of IGF-1 assay was used, $8.3 \%(n=2)$ did not know which assay was used. The most frequently used type of IGF-1 assays were ICMA $(n=17$, $70.8 \%), \operatorname{IRMA}(n=2,8.3 \%)$ and RIA $(n=3,12.5 \%)$. When brands of assay material used for their IGF-1 analysis were asked, 7 respondents $(29.2 \%)$ did not answer this question and 2 respondents (8.3\%) did not know what assay material they were using.

\section{IGF binding protein-3 (IGFBP-3) Assay}

The most frequently used IGFBP-3 assays were reported to be ICMA ( $n=17,70.8 \%)$, IRMA $(n=3,12.5 \%)$ and RIA $(n=1,4.2 \%)$. One center did not perform IGFBP-3 assays and the other two centers did not know what assay they were using. Nine respondents $(37.5 \%)$ did not know the brand of the assay they were using.

\section{Sex Steroid Priming}

Sex steroid priming for both sexes in pre- and peripubertal patients was used by 19 respondents $(79.2 \%)$, whereas 5

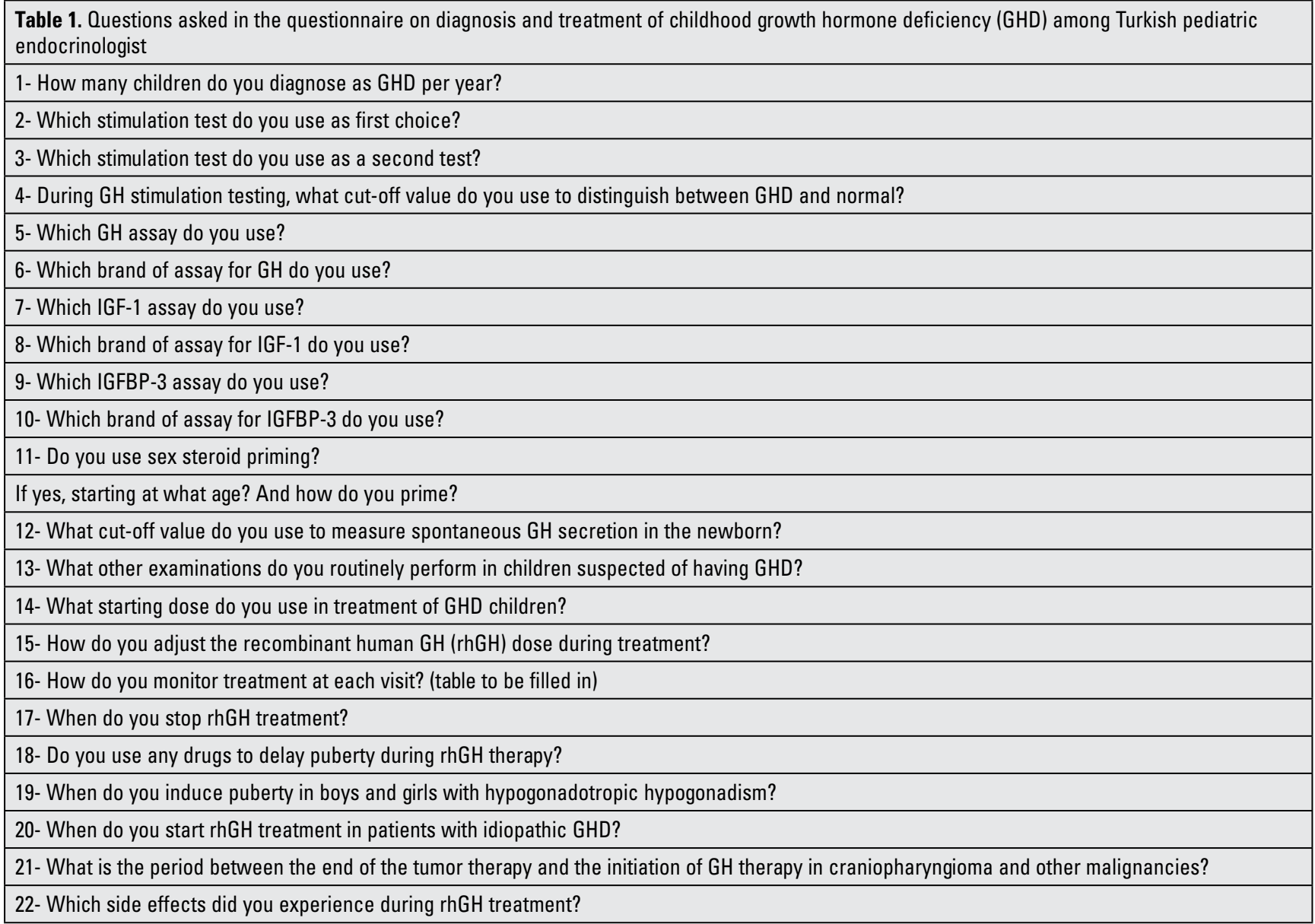


of the centers did not prime with a sex steroid before $\mathrm{GH}$ stimulation testing. Three centers did not state the criteria which they used. Six centers used bone age to decide whether or not priming was necessary and other centers used chronological age (Table 3). For priming, ethinyl estradiol was used $(n=9,47.4 \%)$ most frequently in the girls. Others used 17 $\beta$-estradiol $(n=8,42.1 \%)$ and estradiol valerate $(n=2,10.5 \%)$. For boys, intramuscular administration of

Table 2. Frequency of growth hormone stimulation tests used by centers

\begin{tabular}{|l|l|l|}
\hline Tests & First test [n, (\%)] & Second test [n, (\%)] \\
\hline L-DOPA & $12(50)$ & $9(37.5)$ \\
\hline Clonidine & $9(37.5)$ & $9(37.5)$ \\
\hline Insulin tolerance & $2(8.3)$ & $5(20.8)$ \\
\hline Glucagon & $1(4.2)$ & $1(4.2)$ \\
\hline
\end{tabular}

Table 3. Number of centers using chronological age or bone age for sex steroid priming

\begin{tabular}{|l|l|l|}
\hline Chronological age & Girls & Boys \\
\hline$>9$ yrs & 1 & - \\
\hline$>10$ yrs & 5 & 1 \\
\hline$>11$ yrs & 2 & 2 \\
\hline$>11-12$ yrs & 2 & - \\
\hline$>12$ yrs & - & 4 \\
\hline$>13-14$ & - & 3 \\
\hline Bone age & & \\
\hline$>8$ yrs & 2 & - \\
\hline$>9$ yrs & - & 2 \\
\hline$>10$ yrs & 3 & - \\
\hline$>11$ yrs & 1 & 3 \\
\hline$>13$ yrs & - & 1 \\
\hline
\end{tabular}

long-acting testosterone esters (Sustanon ${ }^{\circledR}$ or Testoviron ${ }^{\circledR}$ ) was used in all centers. The most frequently used dose was $100 \mathrm{mg} \mathrm{IM}$, administered 3-7 days before GH stimulation testing.

\section{Treatment of Growth Hormone Deficiency}

All respondents reported that they adjusted the starting rhGH dose according to body weight. The starting dose of rhGH for prepubertal children was $0.025-0.030 \mathrm{mg} / \mathrm{kg} /$ day in 15 centers $(62.5 \%)$ and $0.031-0.035 \mathrm{mg} / \mathrm{kg} /$ day in 9 centers $(37.5 \%)$. For pubertal children, the dose most commonly used was $0.030-0.035 \mathrm{mg} / \mathrm{kg} /$ day in 16 centers $(66.7 \%)$, 4 centers $(16.7 \%)$ used a dose lower than $0.03 \mathrm{mg} / \mathrm{kg} /$ day and 4 centers $(16.7 \%)$ used a dose higher than 0.035 $\mathrm{mg} / \mathrm{kg} /$ day. $\mathrm{rhGH}$ is administered subcutaneously in the evening on a daily basis in all centers.

All respondents indicated that they performed a cerebral magnetic resonance (MR) scanning in GHD children at the time of diagnosis. Fundoscopic examination of patients was performed in $7(29.2 \%)$ centers before onset of rhGH treatment.

\section{Evaluation of Growth Response of Patients on rhGH Therapy}

All centers used growth velocity and delta height standard deviation score ( $\Delta \mathrm{Ht}$ SDS) on an annual basis in the evaluation of growth response. The response was also evaluated according to IGF-1 $(n=6,25 \%)$ and according to bone age $(n=3,12.5 \%)$. Dose adjustment was made according to growth velocity in all centers and 18 centers also used IGF-1 levels to adjust the dose of rhGH.

\section{Monitoring of rhGH Therapy}

Selection and frequency of the most common laboratory screening tests during therapy are shown in Table 4. All centers evaluated anthropometric measurements of patients every 3-6 months of therapy. Fasting blood glucose, left hand and wrist $x$-ray and thyroid panel evaluation were used by all centers.

Table 4. Frequency (\%) of laboratory screening tests used in centers for monitoring recombinant human growth hormone therapy

\begin{tabular}{|l|l|l|l|l|}
\hline & \multirow{2}{*}{ Test not used (\% of centers) } & \multicolumn{3}{|c|}{ Time of screening after onset of therapy (\% of centers) } \\
\cline { 3 - 5 } & & $\mathbf{3}$ months & $\mathbf{6}$ months & $\mathbf{1 2}$ months \\
\hline Complete blood count & 14.3 & 19 & 38.1 & 33.3 \\
\hline IGF-1 & 4.8 & 28.6 & 38.1 & 33.3 \\
\hline HbA1c & 45.4 & 13.6 & 27.3 & 13.6 \\
\hline Fasting blood glucose & None & 31.8 & 45.5 & 22.7 \\
\hline Liver enzymes & 22.7 & 13.6 & 22.7 & 40.9 \\
\hline Lipid levels & 40.9 & - & 18.2 & 40.9 \\
\hline Thyroid hormone levels & None & 18.2 & 31.8 & 45.5 \\
\hline Cortisol levels & 63.6 & 4.5 & 9 & 22.7 \\
\hline Bone age & None & - & 9 & 91 \\
\hline IGF-1: insulin-like growth factor-1, HbA1c: hemoglobin A1c & & & \\
\hline
\end{tabular}


Poyrazoğlu Ș et al.

Growth Hormone Deficiency in Childhood: Survey

\section{Cessation of rhGH Therapy}

$\mathrm{GH}$ therapy was stopped primarily according to height velocity in all centers and bone age in 22 centers (92\%). Six centers did not give absolute values of height velocity cut-off to stop GH therapy. Height velocity of less than $2 \mathrm{~cm}$ per year was used in $12(50 \%)$ centers, $5 \mathrm{~cm}$ in $4(16.6 \%)$ centers and $4 \mathrm{~cm}$ in 2 (8.3\%) centers. Fourteen centers, which used bone age for cessation of GH treatment, did not report cut-off value for bone age. Bone age cut-off values of greater than 16 years in boys and 14 years in girls were used in $8(33.3 \%)$ centers. Attaining a $25^{\text {th }}$ percentile value in height for age $(n=12,50 \%)$ and attaining target height range $(n=6,25 \%)$ were the other criteria for stopping therapy.

\section{Concomitant Therapy with rhGH During Puberty to Increase Growth Potential}

The practice of using a combination of gonadotropinreleasing hormone analogues $(\mathrm{GnRHa})$ or aromatase inhibitors (boys) and rhGH was asked in the questionnaire. Fourteen centers (58.3\%) used combined treatment with rhGH and $\mathrm{GnRHa}$ to increase the final height by delaying puberty and slowing bone maturation in girls and 7 centers (29.2\%) used aromatase inhibitors in boys.

\section{Induction of Puberty}

In boys with hypogonadotropic hypogonadism, puberty was induced according to chronological age, frequently at 13-14 years (ranging from 11 to 16 years). Six centers did not use chronological age for puberty induction and bone age was used as the criterion for induction. The most commonly used bone age cut-off for puberty induction was a bone age of 12-13 years for boys.

In girls with hypogonadotropic hypogonadism, puberty was induced at 12-13 years of age (ranging from 10 to 14 years). Similar to boys, six centers did not use chronological age for puberty induction in girls and the most commonly used bone age for puberty induction was 11-12 years.

Onset of rhGH Treatment in Idiopathic Growth Hormone Deficiency

rhGH therapy was started after obtaining a pretreatment growth velocity in idiopathic GHD in most of the centers. Most of the centers $(n=17,70.8 \%)$ started $r h G H$ therapy after 6 months of a pretreatment follow-up period.

\section{Onset of rhGH Therapy in Craniopharyngioma and Other Malignancies}

The period between the end of the tumor therapy and the initiation of $\mathrm{rhGH}$ therapy was most frequently 2 years in craniopharyngioma $(n=13,54.2 \%)$. It was 6 months in 4 centers, 1 year in 6 centers and 3 years in 1 center. The period was similar for malignancies other than craniopharyngioma. Most of the centers $(n=15$, $62.5 \%$ ) waited for 2 years in malignancies other than craniopharyngioma. In one center, this waiting period was 6 months, it was 1 year in 3 centers and 3 years in 1 center. One center did not use rhGH treatment in malignancies and 3 centers did not have such patients.

\section{Side Effects of rhGH Treatment}

The most common side effects during rhGH treatment reported in 12 (50\%) centers were benign intracranial hypertension and slipped capital femoral epiphysis. Neoplasms were reported in 3 patients during $\mathrm{GH}$ treatment [osteochondroma $(n=1)$, gastric carcinoid tumor $(n=1)$ and malignant melanoma after optic glioma $(n=1)]$.

\section{Discussion}

We believe that this present survey among pediatric endocrinology centers on current practice in diagnosis and treatment of GHD is of great importance in the preparation of guidelines for diagnosis and treatment of GHD in our country. We have found much conformity among centers in current practice.

Traditionally, GH stimulation tests continue to play a primary role in the diagnosis of GHD. The cut-off levels used to define $\mathrm{GH}$ deficiency are arbitrary. A peak stimulated $\mathrm{GH}$ of less than $10 \mathrm{ng} / \mathrm{mL}$ was the usual cut-off value reported by the centers. Several different stimuli (insulin, L-dopa, clonidine, glucagon, etc.) are currently being used to induce $\mathrm{GH}$ secretion, since they act by different mechanisms. Because the Turkish social security system, for meeting the treatment costs, requires $2 \mathrm{GH}$ stimulation tests to diagnose $\mathrm{GH}$ deficiency, all centers have to confirm the diagnosis of GHD using two separate $\mathrm{GH}$ stimulation tests. Although the use of $\mathrm{GH}$ stimulation test varied among centers, L-dopa was the most frequently used test. The majority of the centers also used clonidine in the first testing. ITT was not among the two most commonly used tests for the diagnosis of $\mathrm{GHD}$, being used in only 2 (8.3\%) centers as a first test and in $5(20.8 \%)$ centers as a second test. GH stimulation tests remain the subject of much controversy and there are significant issues concerning the validity and reproducibility of $\mathrm{GH}$ testing. The low specificity or sensitivity of these tests greatly reduces their diagnostic reliability $(8,9)$. Very low reproducibility has been reported for all stimulation tests in children $(10,11,12,13)$. Although ITT is accepted as the gold standard for the clinical practice (14), $50 \%$ of short prepubertal children with normal height velocity, were also found to have peak serum $\mathrm{GH}$ concentrations during ITT below $10 \mathrm{ng} / \mathrm{mL}$ (15). Tillman et al (16) reported that sensitivity of the $\mathrm{GH}$ stimulation test using a cut-off of $7.5 \mathrm{ng} / \mathrm{mL}$ was $73 \%$ with a specificity of $85 \%$ in a group of children diagnosed with GHD based on clinical and auxological data, along with a group of short children without GHD. Ghigo et al (8) demonstrated, in 
Poyrazoğlu Ş et al.

Growth Hormone Deficiency in Childhood: Survey

a study on 472 children without a diagnosis of GHD and with a normal growth velocity, that the $\mathrm{GH}$ response to a number of stimuli often failed to raise the $\mathrm{GH}$ levels above 7-10 ng/mL. Twenty-three and $49.1 \%$ of the subjects given ITT, L-dopa and clonidine tests have shown a $\mathrm{GH}$ response lower than 7 and $10 \mathrm{ng} / \mathrm{mL}$, respectively. A number of other studies involving $\mathrm{GH}$ stimulation tests in healthy adults and children with normal growth velocity have demonstrated similar rates of false positive results when the cut-off is 10 $\mathrm{ng} / \mathrm{mL}(17,18,19)$.

In our survey, cut-off values for $\mathrm{GH}$ stimulation testing clustered around $10 \mathrm{ng} / \mathrm{mL}$. The arbitrary cut-off level of 10 $\mathrm{ng} / \mathrm{mL}$ was based on $\mathrm{GH}$ values measured by competitive polyclonal radioimmunoassay (20). New monoclonal fully automated non-isotopic assays are able to detect significantly lower $\mathrm{GH}$ levels. $\mathrm{GH}$ levels using newer assays are two to threefold lower than with older assays $(21,22)$. The cut-off of $10 \mathrm{ng} / \mathrm{mL}$ was not useful when monoclonal kits were used. Cut-off for serum GH values as different as $5-10 \mathrm{ng} / \mathrm{mL}$ have been reported. The Canadian Pediatric Endocrine group has reached a consensus defining 8 $\mathrm{ng} / \mathrm{mL}$ as the cut-off level for the diagnosis of GHD in children using the Immulite 2000 assay (23). Tillman et al (16) reported that a peak $\mathrm{GH}$ value less than $7.5 \mathrm{ng} / \mathrm{mL}$ following a $\mathrm{GH}$ provocative test is the most efficient standard for GHD diagnosis. It has also been suggested that the cut-off should be at $7 \mathrm{ng} / \mathrm{mL}$ (24). Similarly, serum random $\mathrm{GH}$ levels in a polyclonal radioimmunoassay of less than 20 $\mathrm{ng} / \mathrm{mL}$ was suggested as a criterion for GHD in the newborn period. Binder et al (25) reported that a single randomly taken $\mathrm{GH}$ level of $<7 \mathrm{ng} / \mathrm{mL}$ confirms the diagnosis of severe GHD with $100 \%$ sensitivity and $98 \%$ specificity by using a highly sensitive GH ELISA. Appropriate adjustment of cut-off levels to $\mathrm{GH}$ assay is a necessary requirement to avoid GHD misdiagnosis in non-GHD short patients. When considering the lower $\mathrm{GH}$ values measured by the current commonly used immunometric assays, an appropriately lower cut-off level for the diagnosis of GHD for both the newborn period and childhood is needed. In our recently prepared guideline, we recommended a cut-off level of 7 $\mathrm{ng} / \mathrm{mL}$ for both the newborn period and childhood. The endocrinologist should be aware of the assay methodology and according to the Guidelines of GH Research Society, when assay data are reported, the method should be clearly indicated (2). However, a survey conducted on European Society for Paediatric Endocrinology (ESPE) members in 2002 revealed that only $63 \%$ of endocrinologist knew what $\mathrm{GH}$ assay they were using (6). Similarly, in the US survey among pediatric endocrinologists in 1995, it was found that only $80 \%$ had knowledge on the type of $\mathrm{GH}$ assay they used (7). It was good to find that all the respondents in our survey knew which $\mathrm{GH}$ assay they were using and most of the respondents also knew which IGF-1 and IGFBP-3 assays they were using.

There is no consensus regarding sex steroid priming for $\mathrm{GH}$ stimulation tests. Although some studies showed that normal prepubertal children may falsely fail $\mathrm{GH}$ stimulation tests $(26,27)$, other studies reported that pubertal stage did not affect $\mathrm{GH}$ response to stimulation $(8,28)$. Sex steroid priming in boys and girls was used by $79.2 \%$ of the respondents and as expected, there were discrepancies with respect to sex steroid priming criteria among centers.

In our survey, the most frequently reported starting doses of $\mathrm{rhGH}(0.025$ to $0.035 \mathrm{mg} / \mathrm{kg} /$ day) were compatible with the recommended doses in international consensus statements and similar to the doses reported by ESPE members $(0.025-0.033 \mathrm{mg} / \mathrm{kg} /$ day), but were lower than the doses reported by $68 \%$ of American pediatric endocrinologists $(0.043 \mathrm{mg} / \mathrm{kg} /$ day) $(1,2,3,4,6,7)$.

rhGH dose adjustment was primarily based on growth velocity as recommended by other consensus publications and all centers in our survey evaluated response and change in height velocity every 3-6 months. It is recommended that $\mathrm{rhGH}$ should be stopped when growth velocity falls to less than $2 \mathrm{~cm} / \mathrm{yr}$ and bone age is greater than 16 years in boys or 14 years in girls (2). Cessation of rhGH therapy was primarily done according to height velocity and bone age in all our centers. Growth velocity accepted by our social security system to continue $\mathrm{rhGH}$ therapy is $5 \mathrm{~cm} / \mathrm{yr}$ and the accepted cut-off for bone age is similar to other consensus results. The Turkish social security system allows using $\mathrm{GH}$ until attainment of a height of $25^{\text {th }}$ percentile for age according to national growth references.

In our survey, fasting blood glucose, left hand and wrist $\mathrm{x}$-ray and thyroid panel were always used by all centers. Lipid profiles, hemoglobin A1c and serum cortisol level were not routinely measured in most of the centers during $\mathrm{rhGH}$ therapy. It is recommended that glucose metabolism be assessed in all patients before and during $\mathrm{rhGH}$ replacement $(2,29)$. Most of the surveillance data do not indicate an increased incidence of type 1 diabetes associated with $\mathrm{rhGH}$ treatment, but an increased risk of type 2 diabetes, especially in the subgroups of patients at risk of diabetes such as Turner's syndrome, Prader-Willi syndrome and intrauterine growth retardation. $\mathrm{rhGH}$ increases the extrathyroidal conversion of thyroxine to triiodothyronine and may as such unmask incipient hypothyroidism. rhGH may also reduce the bioavailability of cortisol through an enhanced conversion of cortisol to cortisone. The possibility of adrenocorticotropic hormone insufficiency to be unmasked during $\mathrm{rhGH}$ replacement should be considered. Regular screening for lipoprotein, liver enzymes 
Poyrazoğlu Ș et al.

Growth Hormone Deficiency in Childhood: Survey

and complete blood count in patients on rhGH therapy is not recommended. Fundoscopic examination should be performed before the initiation of $\mathrm{rhGH}$ treatment for benign intracranial hypertension and repeated when clinically indicated (29). According to our survey, fundoscopic examination was not performed in all centers.

Adequate management of puberty in children with GHD and hypogonadotropic hypogonadism is very important. Puberty should be induced at an appropriate time to ensure normal pubertal development without compromising final height in patients with multiple pituitary hormone deficiencies (MPHD). In our survey, most of the centers preferred to induce puberty at the upper limit of normal age of onset of puberty. These results are very comparable to the results of the ESPE survey $(6,30)$. According to the Growth Hormone Research Society Consensus (2), in MPHD patients in whom puberty does not occur spontaneously, puberty should be initiated at the appropriate time after discussion with the patient. Although not routinely recommended, to improve final height prognosis in children with GHD who are entering into a normally timed puberty and have a poor predicted adult height, combined treatment with $\mathrm{GnRHa}$ and $\mathrm{rhGH}$ may be given in selected cases to arrest pubertal development, to slow bone maturation and to prolong the duration of $\mathrm{GH}$ treatment. In our survey, combined therapy with rhGH to delay puberty was preferred in 14 centers in girl patients with normally timed puberty.

In summary, although we have presented mostly similarities in the current practice in the diagnosis and treatment of childhood GHD among Turkish pediatric endocrinologists compared to international consensus statements, there are some clinical applications that have to be improved in current practice. The items that require more attention are the cut-off values for the diagnosis of GHD, the management of GHD in malignant tumors and establishment of criteria for discontinuation of $\mathrm{GH}$ therapy at follow-up. It is very important to revise guideline statements and to modify, if needed, the approach to GHD over time.

\section{References}

1. Guidelines for the use of growth hormone in children with short stature. A report by the Drug and Therapeutics Committee of the Lawson Wilkins Pediatric Endocrine Society. J Pediatr 1995;127:857-867.

2. Growth Hormone Research Society. Consensus guidelines for the diagnosis and treatment of growth hormone (GH) deficiency in childhood and adolescence: summary statement of the GH Research Society. GH Research Society. J Clin Endocrinol Metab 2000;85:3990-3993.

3. Saggese G, Ranke MB, Saenger P, Rosenfeld RG, Tanaka T, Chaussain JL, Savage MO. Diagnosis and treatment of growth hormone deficiency in children and adolescents: Towards a consensus. Horm Res 1998;50:320-340.
4. Wilson $T A$, Rose $S R$, Cohen $P$, Rogol $A D$, Backeljauw $P_{\text {, }}$ Brown R, Hardin DS, Kemp SF, Lawson M, Radovick S, Rosenthal SM, Silverman L, Speiser P;Lawson Wilkins Pediatric Endocrinology Society Drug and Therapeutics Committee. Update of guidelines for the use of growth hormone in children: the Lawson Wilkins Pediatric Endocrinology Society Drug and Therapeutics Committee. J Pediatr 2003;143:415-421.

5. Cook DM, Rose SR. A review of guidelines for use of growth hormone in pediatric and transition patients. Pituitary 2012;15:301-310.

6. Juul A, Bernasconi S, Clayton PE, Kiess W, DeMuinckKeizer Schrama S; Drugs and Therapeutics Committee of the European Society for Paediatric Endocrinology (ESPE). European audit of current practice in diagnosis and treatment of childhood growth hormone deficiency. Horm Res 2002;58:233-241.

7. Wyatt DT, Mark D, Slyper A. Survey of growth hormone treatment practices by 251 pediatric endocrinologists. J Clin Endocrinol Metab 1995;80:3292-3297.

8. Ghigo E, Bellone J, Aimaretti G, Bellone S, Loche S, Cappa M, Bartolotta E, Dammacco F, Camanni F. Reliability of provocative tests to assess growth hormone secretory status: Study in 472 normally growing children. J Clin Endocrinol Metab 1996;81:3323-3327.

9. Rosenfeld RG, Albertsson-Wikland K, Cassorla F, Frasier SD, Hasegawa Y, Hintz RL, Lafranchi S, Lippe B, Loriaux L, Melmed S. Diagnostic controversy: the diagnosis of childhood growth hormone deficiency revisited. J Clin Endocrinol Metab 1995;80:1532-1540.

10. Tassoni P, Cacciari E, Cau M, Colli C, Tosi M, Zucchini S, Cicognani A, Pirazzoli P, Salardi S,Balsamo A, Frejaville E, Cassio A, Zappulla FVariability of growth hormone response to pharmacological and sleep tests performed twice in short children. J Clin Endocrinol Metab 1990;71:230-234.

11. 11. Dysken MW, Skare SS, Burke MS, Mach JR Jr, Galka T, Billington CJ. Intrasubject reproducibility of growth hormone releasing hormonestimulated growth hormone in older women, older men, and younger men. Biol Psychiatry 1993;33:610-617.

12. Carel JC, Tresca JP, Letrait M, Chaussain JL, Lebouc Y, Job JC, Coste J. Growth hormone testing for the diagnosis of growth hormone deficiency in childhood: A population registerbased study. J Clin Endocrinol Metab 1997;82:21172121.

13. Fisker S, Jørgensen JO, Christiansen JS. Variability in growth hormone stimulation tests. Growth Horm IGF Res 1998;8(Suppl A):31-35.

14. Richmond EJ, Rogol AD. Growth hormone deficiency in children. Pituitary 2008; 11:115-120.

15. Dattani MT, Pringle PJ, Hindmarsh PC, Brook CG. What is a normal stimulated growth hormone concentration? J Endocrinol 1992;133:447-450.

16. Tillmann V, Buckler JM, Kibirige MS, Price DA, Shalet SM, Wales JK, Addison MG, Gill MS, Whatmore AJ, Clayton $\mathrm{PE}$. Biochemical tests in the diagnosis of childhood growth hormone deficiency. J Clin Endocrinol Metab 1997;82:531535.

17. Hoeck HC, Vestergaard P, Jakobsen PE, Laurberg P. Test of growth hormone secretion in adults: poor reproducibility of the insulin tolerance test. Eur J Endocrinol 1995;133:305312. 
Poyrazoğlu S et al.

Growth Hormone Deficiency in Childhood: Survey

18. Zadik Z, Chalew SA, Gilula Z, Kowarski AA. Reproducibility of growth hormone testing procedures: a comparison between 24-h integrated concentration and pharmacological stimulation. J Clin Endocrinol Metab 1990;71:1127-1130.

19. Rahim A, Toogood AA, Shalet SM. The assessment of growth hormone status in normal young adult males using a variety of provocative agents. Clin Endocrinol (Oxf) 1996;45:557-562.

20. Tenenbaum-Rakover $Y$. The need to revise the cut-off level for diagnosis of $\mathrm{GH}$ deficiency in children. Pediatr Endocrinol Rev 2008;5:880-888.

21. Guyda HJ. Growth hormone testing and the short child. Pediatr Res 2000;48:579-580

22. Gandrud LM, Wilson DM. Is growth hormone stimulation testing in children still appropriate? Growth Horm IGF Res 2004;14:185-194.

23. Amed S, Delvin E, Hamilton J. Variation in growth hormone immunoassay in clinical practice in Canada. Horm Res 2008;69:290-294.

24. Banfi G, Marinelli M, Casari, Murone M, Bonini P. Isotopic and nonisotopic assays for measuring somatotropin compared:reevaulation of cutoff value in procovative tests. Clin Chem 1991;37:273-276.

25. Binder G, Weidenkeller M, Blumenstock G, Langkamp M, Weber K, Franz AR. Rational approach to the diagnosis of severe growth hormone deficiency in the newborn. J Clin Endocrinol Metab 2010;95:2219-2226.
26. Marin G, Domené HM, Barnes KM, Blackwell BJ, Cassorla FG, Cutler GB Jr. The effects of estrogen priming and puberty on the growth hormone response to standardized treadmill exercise and arginine-insulin in normal girls and boys. J Clin Endocrinol Metab 1994;79:537-541.

27. Martínez AS, Domené HM, Ropelato MG, Jasper HG, Pennisi PA, Escobar ME, Heinrich JJ. Estrogen priming effect on growth hormone $(\mathrm{GH})$ provocative test: a useful tool for the diagnosis of $\mathrm{GH}$ deficiency. J Clin Endocrinol Metab 2000;85:4168-4172.

28. Cavallo L, Acquafredda A, Liuzzi S, Russo R, Zecchino C, Leuzzi R, Giobbe T, Piacente L. Growth hormone release during insulin tolerance, clonidine, arginine and growth hormone releasing hormone tests in short normal children and adolescents. J Endocrinol Invest 1992;15:131-135.

29. Consensus: Critical Evaluation of the Safety of Recombinant Human Growth Hormone Administration: Statement from the Growth Hormone Research Society. J Clin Endocrinol Metab 2001;86:1868-1870.

30. Kiess W, Conway G, Ritzen M, Rosenfield R, Bernasconi S, Juul A, van Pareren $Y$, de Muinck Keizer-Schrama SM, Bourguignon JP. Induction of puberty in the hypogonadal girl-practices and attitudes of pediatric endocrinologists in Europe. Horm Res 2002;57:66-71. 